\title{
Pharmacological activity and quantitative analysis of flavonoids isolated from the flowers of Begonia semperflorens Link et Otto
}

\author{
Jung-Hwa Kwon', Hyun-Ji Oh', Dong-Sung Lee², Seo-Ji In' ${ }^{1}$, Kyeong-Hwa Seo ${ }^{3}$, Jae-Woo Jung ${ }^{1}$, \\ Byeong-Ju Cha' ${ }^{1}$, Dae Young Lee ${ }^{4^{*}}$ and Nam-In Baek ${ }^{1^{*}}$
}

\begin{abstract}
Begonia semperflorens Link et Otto has been broadly raised up for ornamental purpose as well comestible blossom. As the reproductive structures of phanerogams, flowers contain various secondary metabolites and have many biological activities. Accordingly, we began the contrivance for isolation and analysis of flavonoids contained in B. semperflorens flowers. $\mathrm{MeOH}$ extraction of $B$. semperflorens followed solvent fractionation was prosecuted. Column chromatography of non-polar fraction gave four flavonoids using several resins. Identification of the flavonols were established as quercetin (1), kaempferol (2), astragalin (3), and isoquercetin (4) by interpreting a variety of spectral information. Quercetin (1) and kaempferol (2) inhibited NO production and protected against $t$-BHP-induced oxidative stress. Kaempferol (2) also protected cell death of glutamate-treated HT22. Quantitative analysis of flavonoid content in B. semperflorens flowers was also performed using HPLC experiment.
\end{abstract}

Keywords: Begonia semperflorens, Hepatoprotective, Kaempferol, Neuroprotective, Nitric oxide, Quercetin

\section{Introduction}

A flower, as the reproductive organ of a plant, is pollinated by insects, water, and wind and produces various secondary metabolites, including volatiles, pigments, and flavonoids, for alluring pollinating insects as well definite pollination. Pollinators, especially insects, are attracted by floral colors and scents. Volatile compounds have been suggested as the main drivers of visitation decisions by pollinators [1-3]. Many flowers have UV patterns that are specifically visible to insects, and UV-absorbing pigments concentrated in the center of the flower increase its attractiveness [4].

Flowers have been used as ornamental plants for thousands of years because of their flavors, colors, and pleasing shapes. However, many flowers are also used as food ingredients. KFDA acknowledges approximately twenty

\footnotetext{
*Correspondence: dylee0809@gmail.com; nibaek@khu.ac.kr ${ }^{1}$ Department of Oriental Medicine Biotechnology, Graduate School of Biotechnology, Kyung Hee University, Yongin 17104, Korea ${ }^{4}$ Department Herbal Crop Research, National Institute of Horticultural and Herbal Science, RDA, Eumseong 27709, Korea Full list of author information is available at the end of the article
}

edible flowers including pansies (Viola tricolor), jasmine (Jasminum polyanthum), camellia (Camellia japonica), peaches (Prunus persica), geranium (Pelargonium inquinans), and begonias (Begonia semperflorens). These flowers include a variety of active components showing anti-inflammatory [5], antioxidant [6], antibacterial [7], and NO-inhibition effects [8]. In addition, the Rural Development Administration (RDA) reported that edible flowers contain a 10-fold higher concentration of antioxidant constituents compared to vegetables and fruits. Among the edible flowers, B. semperflorens has a high content of total polyphenols and flavonoids, and NMR and MS analyses have shown it to contain anthocyanins $[9,10]$. Therefore, the flowers of B. semperflorens were also expected to contain polyphenols and flavonoids.

B. semperflorens (Begoniaceae), native to Brazil, is broadly raised in tropical wetlands areas. This plant is in height by $15-45 \mathrm{~cm}$ with broad oval-shaped leaves, and its flowers bloom throughout the growing season until frost. As mentioned above, NMR and MS analyses of B. semperflorens flowers have shown the presence of acylated anthocyanins [11]. The anthocyanin cyanidin 
3-( $2^{\mathrm{G}}$-xylosylrutinoside) was also reported from the leaves of this plant [12]. Anthocyanins provide photoprotection under stressful conditions [9].

In this study, four flavonoids were isolated from $B$. semperflorens flowers using extraction, fractionation as well repeated chromatography. The flavonoids were identified using spectroscopic methods, NMR, IR, MS. The flavonoids were quantitatively analyzed through HPLC experiment. And antioxidant, hepatoprotective, and neuroprotective effects of the flavonoids were then assessed.

\section{Materials and methods \\ Plant materials}

Begonia semperflorens flowers were acquired in Busan flower plantation, Korea, 2017, and Dr. D.G. Kim of Woosuk University, Jeonju, Korea identified. A voucher specimen (NPCL-20170716) was deposited at the Natural Products Chemistry Laboratory of Kyung Hee University, Yongin, Korea.

\section{Reagents and instrumentation}

The reagents and instruments used in this study were same as those used in the previous study [13].

\section{Extraction of Begonia semperflorens flowers and isolation of flavonoids}

Extraction of the fresh flowers of B. semperflorens $(3.0 \mathrm{~kg}$ ) was executed using $100 \%$ methanol $(\mathrm{MeOH}, 18 \mathrm{~L})$ and $80 \%$ aqueous $\mathrm{MeOH}(27 \mathrm{~L} \times 2)$ at r.t. for $24 \mathrm{~h}$. The filtrates were evaporated under reduced pressure to yield an alcohol extract (Ext, $58 \mathrm{~g})$. Ext was added to water $\left(\mathrm{H}_{2} \mathrm{O}, 2 \mathrm{~L}\right)$ and successively fractionated with ethyl acetate (EtOAc, 2 $\mathrm{L} \times 2)$ and $n$-butanol $(n-\mathrm{BuOH}, 2 \mathrm{~L} \times 2)$. The evaporated EtOAc Ext (BSE, $11.2 \mathrm{~g}$ ) was put in application for $\mathrm{SiO}_{2}$ column chromatography $(\mathrm{CC})(7 \times 15 \mathrm{~cm})$ and eluated by $n$-hexane:EtOAc $(15: 1 \rightarrow 10: 1 \rightarrow 7: 1 \rightarrow 3: 1 \rightarrow 1: 1,7 \mathrm{~L}$ of each). Fraction (Fr) BSE-12 (459.0 mg, elution volume/ total volume (VET) 0.772-0.797) was subjected to ODS $\mathrm{CC}(3.5 \times 5 \mathrm{~cm})$ and eluated by acetone: $\mathrm{H}_{2} \mathrm{O}(1: 2,8 \mathrm{~L})$, resulting in 6 Frs (BSE-12-1 to BSE-12-6) with isolation of 1 in BSE-12-3 (4.6 mg, VET 0.070-0.172, TLC using ODS $\mathrm{R}_{\mathrm{f}} 0.51$ in $4: 2$ acetone: $\mathrm{H}_{2} \mathrm{O}$ ). Fr BSE-12-5 (126.5 mg, VET $0.175-0.787)$ was subjected to $\mathrm{SiO}_{2} \mathrm{CC}(2.5 \times 13 \mathrm{~cm})$ and eluated by $\mathrm{CHCl}_{3}: \mathrm{MeOH}: \mathrm{H}_{2} \mathrm{O} \quad(36: 3: 1 \rightarrow 25: 3: 1 \rightarrow 18: 3$ $: 1 \rightarrow 65: 35: 10,470 \mathrm{~mL}$ of each), resulting in 6 Frs (BSE12-5-1 to BSE-12-5-6) with isolation of 2 in Fr BSE-125-2 (3.5 mg, VET 0.118-0.101, TLC using ODS $R_{\mathrm{f}} 0.42$ in 4:2 acetone: $\mathrm{H}_{2} \mathrm{O}$ ). Fr BSE-18 (5.85 g, VET 0.956-1.000) was subjected to $\mathrm{SiO}_{2} \mathrm{CC}(5.0 \times 13 \mathrm{~cm})$ and eluated by $\mathrm{CHCl}_{3}: \mathrm{MeOH}: \mathrm{H}_{2} \mathrm{O}(20: 3: 1,15.7 \mathrm{~L})$, resulting in $20 \mathrm{Frs}$ (BSE-18-1 to BSE-18-20). Fr BSE-18-15 (137.3 mg, VET $0.573-0.725)$ was subjected to $\mathrm{SiO}_{2} \mathrm{CC}(3.0 \times 14 \mathrm{~cm})$ and eluted by $\mathrm{CHCl}_{3}: \mathrm{MeOH}: \mathrm{H}_{2} \mathrm{O}(25: 3: 1 \rightarrow 20: 3: 1,4.1 \mathrm{~L}$ of both), resulting in 7 Frs (BSE-18-15-1 to BSE-18-157) with isolation of 3 in Fr BSE-18-15-2 (6.7 mg, VET 0.257-0.324, TLC using ODS $\mathrm{R}_{\mathrm{f}} 0.43$ in $2: 2$ acetone: $\mathrm{H}_{2} \mathrm{O}$ ) and 4 in Fr BSE-18-15-4 (22.5 mg, VET 0.545-0.665, TLC using ODS $\mathrm{R}_{\mathrm{f}} 0.50$ in 2:2 acetone: $\mathrm{H}_{2} \mathrm{O}$ ).

quercetin (1) yellow crystals; m.p. $277^{\circ} \mathrm{C}$; $\mathrm{IR}_{v}(\mathrm{KBr})$ $3425,1660,1610$, and $1505 \mathrm{~cm}^{-1}$; positive $\mathrm{FAB} / \mathrm{MS}$ (pFABMS) $m / z 303[\mathrm{M}+\mathrm{H}]^{+}$.

kaempferol (2) light yellow crystals; m.p. 178$180{ }^{\circ} \mathrm{C} ; \mathrm{IR}_{v}$ (KBr) 3396, 3021, 2867, 1642, and $1609 \mathrm{~cm}^{-1} ;$ EI/MS $m / z 286[\mathrm{M}]^{+}, 258,229,213,184$, 153, and 121.

astragalin (3) yellow crystals; m.p. $230-232{ }^{\circ} \mathrm{C}$; $[\alpha]_{\mathrm{D}}^{25}+16.0^{\circ} ; \mathrm{IR}_{v}(\mathrm{KBr}) 3420,1680$, and $1628 \mathrm{~cm}^{-1}$; pFABMS $m / z 449[\mathrm{M}+\mathrm{H}]^{+}$and 287.

isoquercetin (4) yellow crystals; m.p. $230-232{ }^{\circ} \mathrm{C}$; $[\alpha]_{\mathrm{D}}^{25} 230-231^{\circ} ; \mathrm{IR}_{v}(\mathrm{KBr}) 3400,2919,1656,1606$, and $1508 \mathrm{~cm}^{-1}$; pFABMS $\mathrm{m} / z 465[\mathrm{M}+\mathrm{H}]^{+}, 447,423$, 389, 297, and 204.

${ }^{1} \mathrm{H}-\mathrm{NMR} \quad\left(400 \mathrm{MHz}, \mathrm{CD}_{3} \mathrm{OD}, \delta_{\mathrm{H}}\right)$ and ${ }^{13} \mathrm{C}-\mathrm{NMR}$ $\left(100 \mathrm{MHz}, \mathrm{CD}_{3} \mathrm{OD}, \delta_{\mathrm{C}}\right)$ see Table 1.

\section{Inhibitory effects on NO production in LPS-induced RAW 264.7}

Cell culture of murine macrophage RAW 264.7 cells and measurement of nitrite (NO) production can be referred to literature [14]. Butein was used as a positive control.

\section{Protective effect on cell death of glutamate-treated HT22}

Cytoprotective effect was assayed according to the same methods reported in literature [15]. Trolox was used as a positive control.

\section{Protective effect on oxidative stress in treated HepG2 cells by $t$-BHP}

Human hepatoma HepG2 cell culture and Hepatoprotective effect assay was accomplished using the same method reported in the previous study [14]. Curcumin was used as a positive control.

\section{Quantitative analysis of the flavonoids isolated from Begonia semperflorens flowers}

The MeOH Ext of B. semperflorens flowers was fractionated using EtOAc and $\mathrm{H}_{2} \mathrm{O}$. The organic phase Fr was utilized to analyze the isolated flavonoids. The flavonoids were diluted to various concentrations to establish calibration curves (1: 1.890625, 3.78125, 7.5625, 15.125, and $31.25 \mu \mathrm{g} / \mathrm{mL} ; 2: 3.78125,7.5625,15.125,31.25$, and $62.5 \mu \mathrm{g} / \mathrm{mL} ; 3$ and $4: 15.125,31.25,62.5,125,250 \mu \mathrm{g} / \mathrm{mL})$.

The equipment and materials for HPLC analysis were as the followings. An Waters 600S (Milford, MA), a 
Table $1{ }^{1} \mathrm{H}$ - (400 MHz) and ${ }^{13} \mathrm{C}-\mathrm{NMR}(100 \mathrm{MHz})$ data of compounds 1-4 from Begonia semperflorens flowers (CD ${ }_{3}$ OD)

\begin{tabular}{|c|c|c|c|c|c|c|c|c|}
\hline \multirow{2}{*}{$\begin{array}{l}\text { Carbon } \\
\text { number }\end{array}$} & \multicolumn{4}{|l|}{$\delta_{c}$} & \multicolumn{4}{|c|}{$\delta_{\mathrm{H}}$, coupling pattern, $J$ in $\mathrm{Hz}$} \\
\hline & 1 & 2 & 3 & 4 & 1 & 2 & 3 & 4 \\
\hline 2 & 147.59 & 148.06 & 158.54 & 158.99 & & & & \\
\hline 3 & 137.70 & 137.27 & 135.47 & 135.63 & & & & \\
\hline 4 & 177.12 & 177.45 & 179.51 & 179.42 & & & & \\
\hline 5 & 162.28 & 162.53 & 162.80 & 162.97 & & & & \\
\hline 6 & 99.09 & 99.28 & 99.96 & 99.89 & 6.73, br. s & $6.16, d, 2.0$ & $6.19, d, 2.0$ & 6.17, br. s \\
\hline 7 & 165.37 & 165.92 & 166.13 & 165.96 & & & & \\
\hline 8 & 94.16 & 94.45 & 94.80 & 94.72 & $6.68, \mathrm{br}, \mathrm{s}$ & $6.36, d, 2.0$ & $6.39, d, 2.0$ & 6.36, br. s \\
\hline 9 & 157.33 & 158.26 & 159.08 & 158.39 & & & & \\
\hline 10 & 104.31 & 104.54 & 104.09 & 105.48 & & & & \\
\hline $1^{\prime}$ & 123.43 & 123.76 & 122.80 & 122.92 & & & & \\
\hline $2^{\prime}$ & 116.48 & 130.66 & 132.28 & 117.58 & 8.55, br. s & $8.07, d, 9.2$ & $8.05, d, 8.8$ & $7.70, d, 2.0$ \\
\hline $3^{\prime}$ & 149.66 & 116.30 & 116.08 & 145.84 & & $6.89, d, 9.2$ & $6.88, d, 9.2$ & \\
\hline $4^{\prime}$ & 146.91 & 160.54 & 161.58 & 149.82 & & & & \\
\hline $5^{\prime}$ & 116.48 & 116.30 & 116.08 & 115.98 & $7.35, d, 8.4$ & $6.89, d, 9.2$ & $6.88, d, 9.2$ & $6.85, \mathrm{~d}, 8.4$ \\
\hline $6^{\prime}$ & 120.93 & 130.66 & 132.28 & 123.19 & 8.08 , br. d, 8.4 & $8.07, d, 9.2$ & $8.05, d, 8.8$ & $7.56, \mathrm{dd}, 8.4,2.0$ \\
\hline $1^{\prime \prime}$ & & & 104.09 & 104.41 & & & $5.24, d, 7.2$ & $5.22, d, 7.2$ \\
\hline $2^{\prime \prime}$ & & & 75.74 & 75.70 & & & & \\
\hline $3^{\prime \prime}$ & & & 78.43 & 78.32 & & & & \\
\hline $4^{\prime \prime}$ & & & 71.37 & 71.17 & & & & \\
\hline $5^{\prime \prime}$ & & & 78.05 & 78.08 & & & & \\
\hline $6^{\prime \prime}$ & & & 62.64 & 62.53 & & & $\begin{array}{l}3.68, \mathrm{dd}, 12.0,2.4 \\
3.52, \mathrm{dd}, 12.0,5.2\end{array}$ & $\begin{array}{l}3.71, \mathrm{dd}, 12.0,2.4 \\
3.58, \mathrm{dd}, 12.0,5.2\end{array}$ \\
\hline
\end{tabular}

reverse phase column (Waters $\mathrm{C}_{18}, 5 \mu \mathrm{m}, 250 \times 4.6 \mathrm{~mm}$ ). The eluting solvents, aqueous $0.05 \%$ trifluoroacetic acid (A) and $100 \%$ acetonitrile (B). $0.6 \mathrm{~mL} / \mathrm{min}$ with gradient of B: $0-5 \mathrm{~min}, 10-30 \%$; 5-20 $\mathrm{min}, 30 \%$; 20-23 $\mathrm{min}$, 30-40\%; 23-38 min, 40\%; 38-43 min, 40-100\%. Injection volume, $10 \mu \mathrm{L}$. Detection was carried out using a photodiode spectrophotometer at $280 \mathrm{~nm}$. The analysis was repeated three times.

\section{Results and discussion}

TLC for alcohol Ext of B. semperflorens flowers revealed yellow spots after spraying with a $10 \% \mathrm{H}_{2} \mathrm{SO}_{4}$ solution and heating, indicating the presence of flavonoids in the Ext. The Ext was fractionated into EtOAc, $n-\mathrm{BuOH}$, and $\mathrm{H}_{2} \mathrm{O}$ Frs through solvent fractionation. And repeated $\mathrm{SiO}_{2}$ and ODS CC of EtOAc Fr afforded four flavonoid compounds. All compounds were isolated as yellow crystals and exhibited yellow spots on TLC plate after by same treatment, which led to deduction that they were flavonoids. The UV absorption pattern of the compounds confirmed the above-mentioned ratiocination.

The molecular weight (MW) of $\mathbf{1}$ was determined to be 302 amu based on the molecular ion peak (MIP) $[\mathrm{M}+\mathrm{H}]^{+}$at $m / z 303$ in the pFABMS. IR spectrum showed absorption peaks at $3425(\mathrm{OH}), 1660$ (conjugated ketone), and $1610 \mathrm{~cm}^{-1}$ (aromatic double bond). The ${ }^{1} \mathrm{H}$ NMR (PMR) spectrum (400 MHz, CD 3 OD) showed two olefin methine proton signals at $\delta_{\mathrm{H}} 6.68$ (br. s, $\mathrm{H}-8$ ) and 6.73 (br. s, H-6) due to a 1,2,3,5-tetrasubstituted benzene ring and three olefin methine proton signals at $7.35(\mathrm{~d}$, $J=8.4 \mathrm{~Hz}, \mathrm{H}-5^{\prime}$, coupling pattern, coupling constant in $J$ in $\mathrm{Hz}$ ), $\delta_{\mathrm{H}} 8.08$ (br. d, $8.4, \mathrm{H}-6^{\prime}$ ) and 8.55 (br. s, H-2' due to a 1,2,4-trisubstituted benzene ring. The ${ }^{13} \mathrm{C}$-NMR (CMR) (100 MHz, CD $\left.\mathrm{CD}_{3} \mathrm{O}\right)$ spectrum included 15 carbon signals, suggesting 1 was a flavonoid. The five olefin methine carbon signals at $\delta_{\mathrm{C}} 94.16$ (C-8), 99.09 (C-6), $116.48\left(\mathrm{C}-5^{\prime}\right), 116.48\left(\mathrm{C}-2^{\prime}\right)$, and $120.93\left(\mathrm{C}-6^{\prime}\right)$; two olefin quaternary carbon signals at $104.31(\mathrm{C}-10)$ and $\delta_{\mathrm{C}}$ $123.43\left(\mathrm{C}-1^{\prime}\right)$; seven oxygenated olefin quaternary carbon signals at $\delta_{\mathrm{C}} 137.7$ (C-3), $146.91\left(\mathrm{C}-4^{\prime}\right), 147.59(\mathrm{C}-2)$, 149.66 (C-3'), 157.33 (C-9), 162.28 (C-5), and 165.37 (C-7); one conjugated ketone carbon signal at $\delta_{C} 177.12$ (C-4) suggested that $\mathbf{1}$ was a flavonol. 1 was identified to be quercetin through intensive analysis of 2D-NMR (i.e., gHSQC and gHMBC) data as well comparison of the spectroscopic data with reported literature [16].

$\mathbf{2}$ showed very similar NMR signals to those of $\mathbf{1}$ with the exception of the B-ring structure. The PMR signals 
of a para-substituted benzene ring at $\delta_{\mathrm{H}} 6.89(2 \mathrm{H}, \mathrm{d}, 9.2$, $\left.\mathrm{H}-3^{\prime}, 5^{\prime}\right)$ and $8.07\left(2 \mathrm{H}, \mathrm{d}, 9.2, \mathrm{H}-2^{\prime}, 6^{\prime}\right)$, as well the CMR signals of four olefin methines at $\delta_{\mathrm{C}} 116.30\left(\mathrm{C}-3^{\prime}, 5^{\prime}\right)$ and $130.66\left(\mathrm{C}-2^{\prime}, 6^{\prime}\right)$, one olefin quaternary at $\delta_{\mathrm{C}} 123.76\left(\mathrm{C}-1^{\prime}\right)$, and one oxygenated olefin quaternary at $\delta_{\mathrm{C}} 160.54\left(\mathrm{C}-4^{\prime}\right)$ indicated that 2 was 5,7,4'-trihydroxyflavonol, kaempferol. The identification of $\mathbf{2}$ was confirmed through the molecular weight (MW) of $286 \mathrm{amu}$, which was $16 \mathrm{amu}$ less than that of $\mathbf{1}$.

3 showed similar NMR signals as those of 2 with the exception of additional signals due to a $\beta$-glucopyranose. The hemiacetal PMR signal at $\delta_{\mathrm{H}} 5.24\left(\mathrm{~d}, 7.2, \mathrm{H}-1^{\prime \prime}\right)$ and the chemical shifts of CMR signals confirmed the presence of a $\beta$-glucopyranosyl moiety. MW of $\mathbf{3}$ was determined to be $448 \mathrm{amu}$ from a MIP $[\mathrm{M}+\mathrm{H}]^{+}$at $m / z 449$ in FABMS spectra, which was 162 amu more than that of 2 . The $\beta$-glucopyranose was revealed to be linked to the 3-OH in the C-ring from the cross-peak between the anomeric PMR signal at $\delta_{\mathrm{H}} 5.24\left(\mathrm{~d}, 7.2, \mathrm{H}-1^{\prime \prime}\right)$ and an oxygenated olefin quaternary CMR signal at $\delta_{\mathrm{C}} 135.47(\mathrm{C}-3)$ in the gHMBC spectrum. 3 was identified to be kaempferol 3-O- $\beta$-D-glucopyranoside, astragalin.

4 showed similar NMR signals as those of $\mathbf{1}$ with the exception of additional $\beta$-glucopyranose signals. The hemiacetal PMR signal at $\delta_{\mathrm{H}} 5.22\left(\mathrm{~d}, 7.2, \mathrm{H}-1^{\prime \prime}\right)$ and the chemical shifts of CMR signals confirmed the presence of a $\beta$-glucopyranosyl moiety. MW was determined to be 464 amu from MIP $[\mathrm{M}+\mathrm{H}]^{+}$at $m / z 465$ in pFABMS spectrum, which was 162 amu more than that of $\mathbf{1}$. The 3 -OH linkage of the $\beta$-glucopyranose was determined from the cross-peak between the anomeric PMR signal at $\delta_{\mathrm{H}} 5.22\left(\mathrm{~d}, 7.2, \mathrm{H}-1^{\prime \prime}\right)$ and an oxygenated olefin quaternary CMR signal at $\delta_{\mathrm{C}} 135.63(\mathrm{C}-3)$ in the gHMBC spectrum. 4 was identified to be quercetin $3-O-\beta$-Dglucopyranoside, isoquercetin. This study is the first report for isolation of the flavonoids from $B$. semperflorens flowers.

\section{Inhibitory effects on NO production in RAW 264.7 treated by LPS}

1 and 2 were estimated for inhibition effect against NO generation in LPS-treated RAW 264.7. LPS-stimulated macrophages were treated with each compound (1: 1, $5,10$, or $20 \mu \mathrm{M} ; 2: 5,10,20$, or $40 \mu \mathrm{M})$. As can be seen in Fig. 1, 1 and 2 dose-dependently suppressed NO production in RAW 264.7. 1 and $\mathbf{2}$ showed slightly lower effect than butein. $\mathrm{IC}_{50}$ value of $\mathbf{1}$ and $\mathbf{2}$ was respectively estimated as 84.79 and $80.87 \mu \mathrm{M}$. Previous studies have also reported the suppressive activity of $\mathbf{1}$ and $\mathbf{2}$ on NO generation. Naturally occurring flavonoids are known to modulate various inflammatory and immune processes. Genistein inhibits NO synthase expression and NO generation with $\mathrm{IC}_{50}$ value, $26.8 \mu \mathrm{M}$ [17].

\section{Neuroprotective effects against glutamate-induced cell death in HT22}

1-4 were investigated for their protective effects against glutamate-induced cell death in HT22 cells. Glutamatestimulated HT-22 cells were treated with the compounds and trolox $(100 \mu \mathrm{M})$. As shown in Fig. 2, 2 showed considerable protection (99.1\%) against glutamate-induced toxicity at the low concentration at $80 \mu \mathrm{M}$, which was a

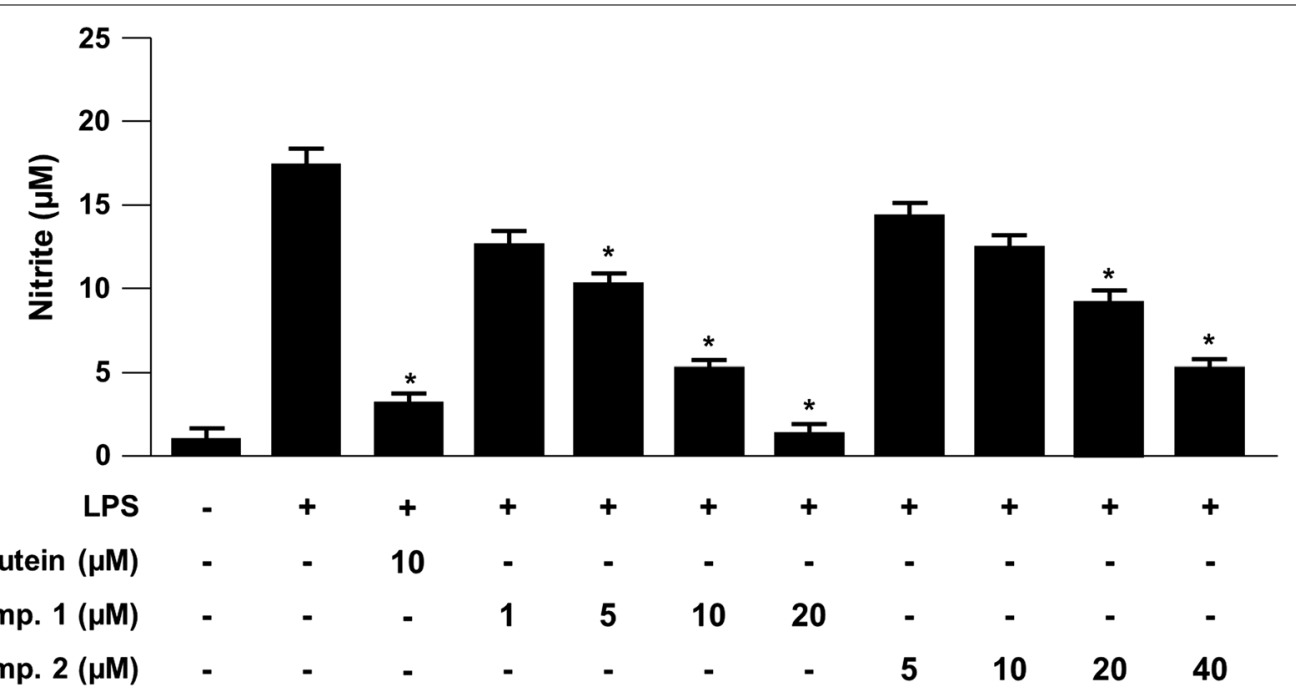

Fig. 1 Inhibitory activity of $\mathbf{1}$ and $\mathbf{2}$ on NO generation in RAW 264.7 induced by LPS. The cells were pretreated for $12 \mathrm{~h}$ with the indicated concentrations of compounds and stimulated for $18 \mathrm{~h}$ with LPS $(1 \mu \mathrm{g} / \mathrm{mL})$. The error bars represent the mean \pm SD of three independent experiments. ${ }^{*} p<0.05$ compared to the LPS-treated control group. Positive control, butein 


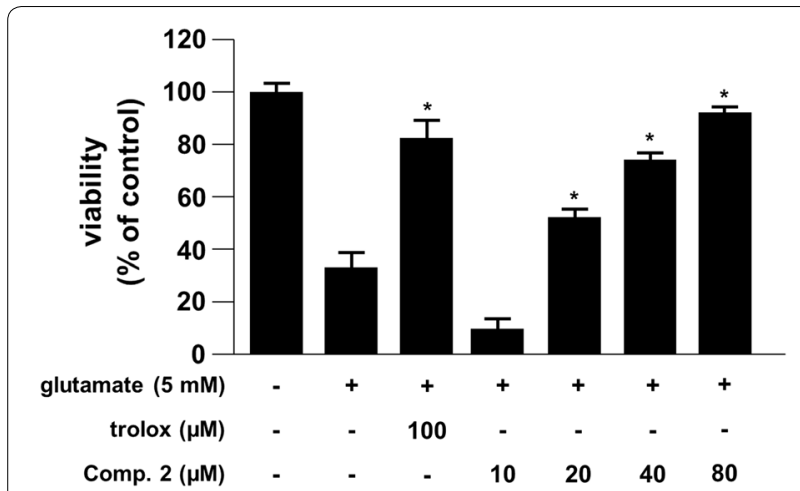

Fig. 2 Neuroprotective activity against cell death in HT22 cells treated by glutamate. Treatment of HT22 with $5 \mu \mathrm{M}$ glutamate raised the formation of ROS. The error bars represent the mean \pm SD of three independent tests. ${ }^{*} p<0.05$ compared with glutamate-treated group. Positive control, trolox

higher protective effect than trolox $(82.0 \%, 100 \mu \mathrm{M})$. The $\mathrm{EC}_{50}$ value of 2 was $19.95 \mu \mathrm{M}$. A previous study reported that $2(100 \mu \mathrm{M})$ protected HT22 cells against glutamateinduced cytotoxicity by $62.4 \pm 2.8 \%$ [18].

\section{Hepatoprotective activity against oxidative stress in t-BHP-induced HepG2}

To examine the protective effect against $t$-BHP-induced oxidative stress in HepG2, the cells were treated with 1 and $2(1: 5,10,20$, or $40 \mu \mathrm{M} ; 2: 10,20,40$, or $80 \mu \mathrm{M})$ or curcumin $(20 \mu \mathrm{M})$. As shown in Fig. 3, 1 and 2 showed high protective effects (86.5 and $78.7 \%$, respectively) against $t$-BHP-induced cytotoxicity at a concentration of $20 \mu \mathrm{M}$, which was almost the same as that of the positive control, curcumin. $\mathrm{EC}_{50}$ value of $\mathbf{1}$ and $\mathbf{2}$ was calculated to be 1.019 and $5.321 \mu \mathrm{M}$, respectively. A previous study also reported $\mathbf{1}$ to show protective effect against $t$-BHPinduced oxidative stress [19].

Many flavonoids have been shown to have various pharmacological activities. Quercetin (1) is effective against inflammation, arteriosclerosis, bleeding, allergies, and swelling [10, 20]. Kaempferol (2) has antidiabetic [21] and antioxidant as well as anticancer [22] activities. Astragalin (3) exhibits antioxidant [23], anti-HIV [24], and anti-allergen [25] activities, and isoquercetin (4) shows antioxidant [26], anti-inflammatory [27], and antitumor [28] activities. Compounds $\mathbf{1}$ and $\mathbf{2}$ were proved to have anti-inflammatory, neuroprotective, and hepatoprotective effects through our experiments and previous studies as well. The compounds are sure to have potential to be developed as new drugs.

\section{Quantitative HPLC analysis of the flavonoids in Begonia semperflorens flowers}

Using HPLC, each flavonoid peak was clearly separated and identified through comparison of the retention time with those of the standards (Fig. 4). The calibration curves were built using various concentrations of each compound (1: 1.890625, 3.78125, 7.5625, 15.125, and $31.25 \mu \mathrm{g} / \mathrm{mL} ; 2: 3.78125,7.5625,15.125,31.25$, and $62.5 \mu \mathrm{g} / \mathrm{mL} ; 3$ and $4: 15.125,31.25,62.5,125$, and $250 \mu \mathrm{g} /$ $\mathrm{mL})$. The regression equations and correlation coefficient $\left(r^{2} 0.9996-1.000\right)$ for $\mathbf{1}-\mathbf{4}$ are listed in Table 2 . The

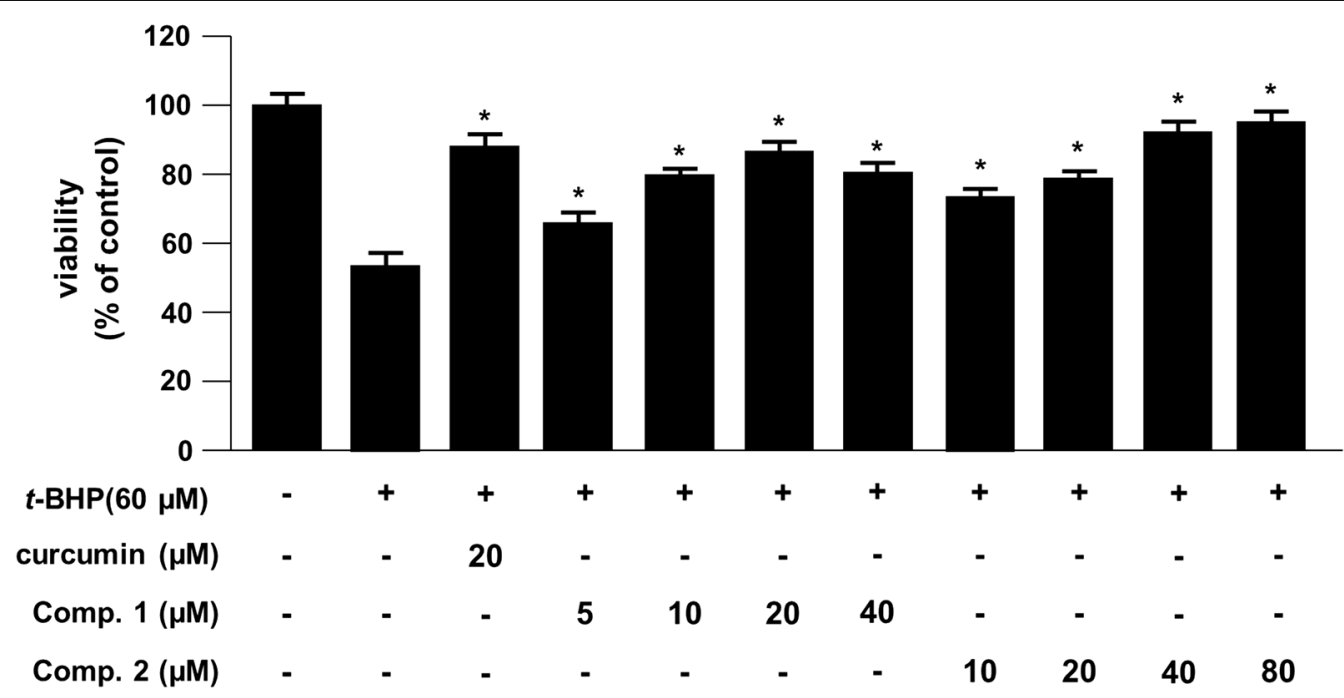

Fig. 3 Hepatoprotective activity against oxidative stress in t-BHP-induced HepG2. Cytotoxicity was estimated after incubating the cells with 60 MM $t$-BHP in RPMI. The error bars represent the mean \pm SD of three independent tests. ${ }^{*} p<0.05$ compared with $t$-BHP-treated group. Positive control, curcumin 


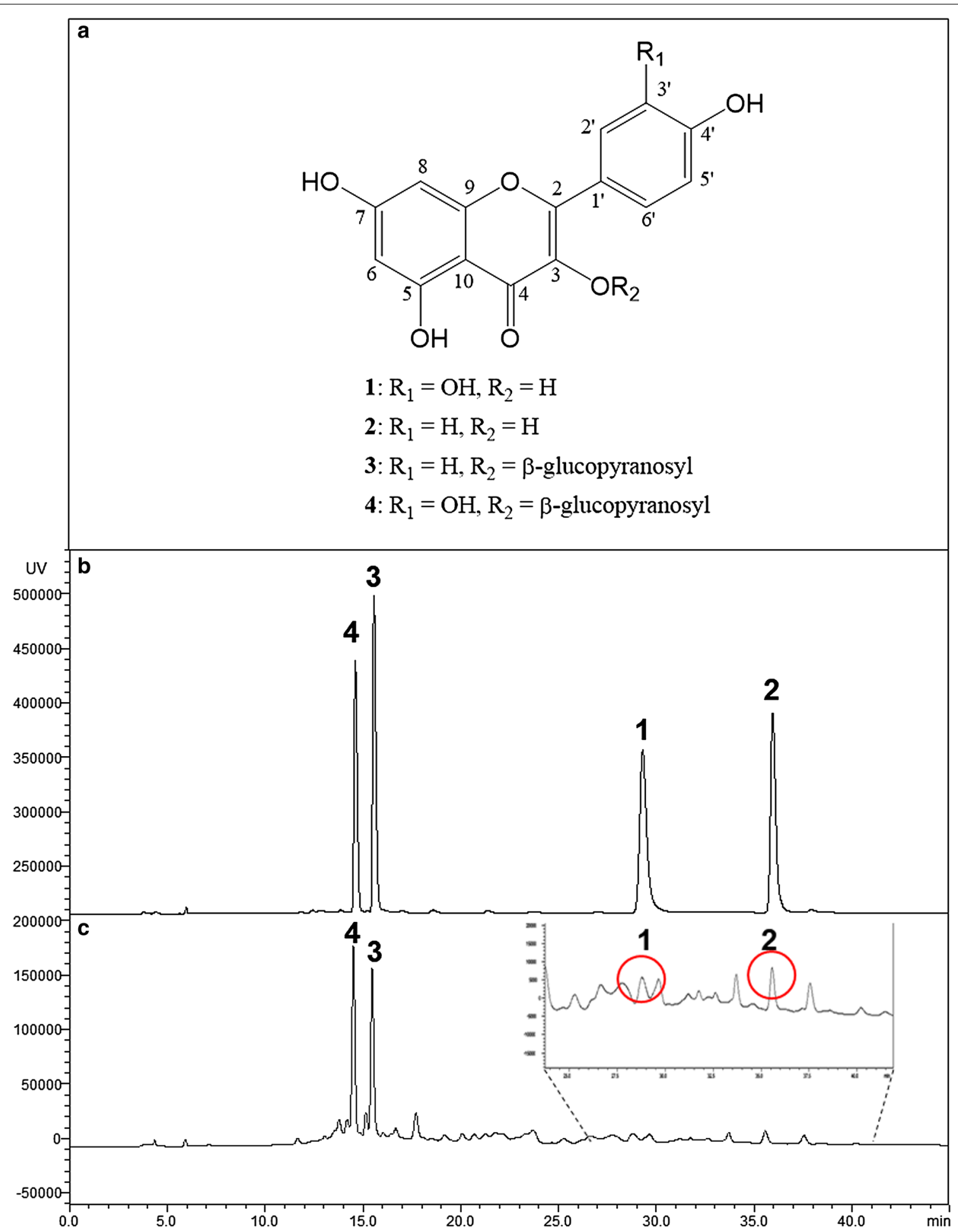

Fig. 4 Molecular structures of flavonoids from Begonia semperflorens flowers. a HPLC chromatogram of the isolated flavonoids (b) and EtOAC fraction (c) from the flowers of Begonia semperflorens. 1 (quercetin, rt: 29.3'), 2 (kaempferol, rt: 36.0'), 3 (astragalin, rt: 15.6'), 4 (isoquercetin, rt: 14.6') 
Table 2 Contents of flavonoids in EtOAc fraction of Begonia semperflorens flowers

\begin{tabular}{llllc}
\hline Compound & RT (min) & Calibration curve fit & $\boldsymbol{R}^{\mathbf{2}}$ & Content (\%) \\
\hline $\mathbf{1}$ & 29.3 & $\begin{array}{l}y=25,644.2202 x- \\
40,789\end{array}$ & 0.9997 & $0.3 \pm 0.02$ \\
$\mathbf{2}$ & 36.0 & $y=18,150 x-10,7941$ & 0.9997 & $0.8 \pm 0.09$ \\
$\mathbf{3}$ & 15.6 & $y=49,027 x-35,220$ & 1.0000 & $7.1 \pm 0.16$ \\
$\mathbf{4}$ & 14.6 & $y=24,033 x-32,222$ & 0.9996 & $11.9 \pm 0.03$ \\
\hline
\end{tabular}

$y=$ area units, $x=$ concentration in standard solution (ppm)

high value of each $r^{2}$ confirmed this analysis to be reliable. The concentrations of 1-4 were determined using the peak areas in the chromatogram and the regression equations (Table 2). The contents of $\mathbf{1 - 4}$ in the EtOAc Fr were calculated to be $0.3 \pm 0.02,0.8 \pm 0.09,7.1 \pm 0.16$, and $11.9 \pm 0.03 \%$, respectively.

\section{Authors' contributions}

$\mathrm{J}-\mathrm{HK}$ and $\mathrm{H}-\mathrm{JO}$ isolated the compounds and elucidated the structures; J-WJ contributed to the plant materials preparation; D-SL carried out the biological assay and helped with the preparation of the manuscript; S-J and K-HS performed the NMRs, and HPLC of the samples; DYL assisted the revision of the manuscript; J-WK wrote the paper; N-IB designed and managed the research project. All authors read and approved the final manuscript.

\section{Author details}

${ }^{1}$ Department of Oriental Medicine Biotechnology, Graduate School of Biotechnology, Kyung Hee University, Yongin 17104, Korea. ${ }^{2}$ Chosun University, Gwangju 61452, Korea. ${ }^{3}$ Biological and Genetic Resources Utilization Division, National Institute of Biological Resources, Incheon 22689, Korea. ${ }^{4}$ Department Herbal Crop Research, National Institute of Horticultural and Herbal Science, RDA, Eumseong 27709, Korea.

\section{Acknowledgements}

This work was supported by the Korean Institute of Planning and Evaluation for Technology in Food, Agriculture, Forestry, and Fisheries (317071-03-2-SB020).

\section{Competing interests}

The authors declare that they have no competing interests.

\section{Funding}

The funding sponsors had no role in the design of the study; collection, analyses, or interpretation of the data; writing of themanuscript; or the decision to publish the results.

\section{Publisher's Note}

Springer Nature remains neutral with regard to jurisdictional claims in published maps and institutional affiliations.

Received: 20 December 2018 Accepted: 31 January 2019

Published online: 05 March 2019

\section{References}

1. Dötterl S, Vereecken NJ (2010) The chemical ecology and evolution of bee-flower interactions: a review and perspectives. Can J Zool 88:668-697

2. Raguso RA (2008) Wake up and smell the roses: the ecology and evolution of floral scent. Annu Rev Ecol Evol Systemat 39:549-569
3. Wright GA, Schiestl FP (2009) The evolution of floral scent: the influence of olfactory learning by insect pollinators on the honest signalling of floral rewards. Funct Ecol 23:841-851

4. Gronquist M, Bezzerides A, Attygalle A, Meinwald J, Eisner M, Eisner T (2001) Attractive and defensive functions of the ultraviolet pitments of a flower (Hypericum calycinum). Proc Natl Acad Sci USA 98:13745-13750

5. Lee HH, Cho JY, Moon JH, Park KH (2011) Isolation and identification of antioxidative phenolic acid and flavonoid glycosides from Camellia japonica flowers. Hort Environ Biotechnol 52:270-277

6. Chung TY, Kim MA, Jones AD (1996) Antioxidative activity of flavonoids isolated from Jindalrae flowers (Rhododendron mucronulatum Turcz.). Agric Chem Biotechnol 39:320-326

7. Rashid F, Ahmed R, Mahmood A, Bibi N, Kazmi SU (2007) Flavonoid glycosides from Prunus armeniaca and the antibacterial activity of a crude extract. Arch Pharm Res 30:932-937

8. Lee DG, Lee SM, Bang MH, Park HJ, Lee TH, Kim YH, Kim JY, Baek NI (2011) Lignans from the flower of Osmanthus fragrans var. aurantiacus and their inhibition effect on NO production. Arch Pharm Res 34:2029-2035

9. Zhang KM, Yu HJ, Shi K, Zhou YH, Yu JQ, Xia XJ (2010) Photoprotective roles of anthocyanins in Begonia semperflorens. Plant Sci 179:202-208

10. Formica JV, Regelson W (1995) Review of the biology of quercetin and related bioflavonoids. Food Chem Toxicol 33:1061-1080

11. Chirol N, Jay M (1995) Acylated anthocyanins from flowers of Begonia. Phytochemistry 40:275-277

12. Ji S, Yokoi M, Saito N, Ueda Y, Shigihara A, Honda T (1995) Cyanidin 3-( $2^{G}$-xylosylrutinoside) from brown-red spring leaves of Acer macrophyllum and Begonia semperflorens cultivars. Tech Bull Fac Hort Chiba Univ 49:13-17

13. Seo KH, Nam YH, Lee DY, Ahn EM, Kang TH, Baek NI (2015) Recovery effect of phenylpropanoid glycosides from Magnolia obovata fruit on alloxaninduced pancreatic islet damage in zebrafish (Danio rerio). Carbohydr Res 416:70-74

14. Jung YJ, Park JH, Seo KH, Shrestha S, Lee DS, Kim YC, Kang HC, Kim J, Baek $\mathrm{NI}$ (2014) Phenolic compounds from the stems of Zea mays and their pharmacological activity. J Korean Soc Appl Biol Chem 57:379-385

15. Jung YJ, Park JH, Cho JG, Seo KH, Lee DS, Kim YC, Kang HC, Song MC, Baek $\mathrm{NI}$ (2015) Lignan and flavonoids from the stems of Zea mays and their anti-inflammatory and neuroprotective activities. Arch Pharmacal Res 38:178-185

16. Aisyah LS, Yun YF, Herlina T, Julaeha E, Zainuddin A, Nurfarida I, Hidayat AT, Supratman U, Shiono Y (2017) Flavonoid compounds from the leaves of Kalanchoe prolifera and their cytotoxic activity against P-388 murine leukimia cells. Nat Prod Sci 23:139-145

17. Kim AR, Cho JY, Zou Y, Choi JS, Chung HY (2005) Flavonoids differentially modulate nitric oxide production pathways in lipopolysaccharide-activated RAW 264.7 cells. Arch Pharm Res 28:297-304

18. Taechowisan T, Chuaychot N, Chanaphat S, Wanbanjob A, Shen Y (2009) Cytoprotective activity of chemical constituents isolated from Streptomyces sp. Int J Biol Chem 3:11-17

19. Saw $C L$, Guo Y, Yang AY, Paredes-Gonzalez X, Ramirez C, Pung D, Kong AT (2014) The berry constituents quercetin, kaempferol, and pterostilbene synergistically attenuate reactive oxygen species: involvement of the Nrf2-ARE signaling pathway. Food Chem Toxicol 72:303-311

20. Havsten B (1983) Flavonoids, A class of natural products of high pharmacological potency. Biochem Pharmacol 32:1141-1148

21. Yoo NH, Jang DS, Yoo JL, Lee YM, Kim YS, Cho JH, Kim JS (2008) Erigeroflavanone, a flavanone derivative from the flowers of Erigeron annuus with protein glycation and aldose reductase inhibitory activity. J Nat Prod 71:713-715

22. Li S, Yan T, Deng R, Jiang $X$, Xiong H, Wang Y, Yu Q, Wang X, Chen C, Zhu $Y$ (2017) Low dose of kaempferol suppresses the migration and invasion of triple-negative breast cancer cells by downregulating the activities of RhoA and Rac1. Onco Targets Ther 10:1-11

23. Choi JW, Kang HJ, Kim SZ, Kwon TO, Jeong SI, Jang SI (2013) Antioxidant effect of astragalin isolated from the leaves of Morus alba L. against free radical-induced oxidative hemolysis of human red blood cells. Arch Pharm Res 36:912-917

24. Lin YM, Anderson H, Flavin MT, Pai YH, Mata-Greenwood E, Pengsuparp T, Pezzuto JM, Schinazi RF, Hughes SH, Chen FC (1997) In vitro anti-HIV activity of biflavonoids isolated from Rhus succedanea and Garcinia multiflora. J Nat Prod 60:884-888 
25. Matsumoto M, Kotani A, Fujita S, Higa T, Kishimoto M, Suemura T, Tanaka $\mathrm{T}$ (2002) Oral administration of persimmon leaf extract ameliorates skin symptoms and trasepidermal water loss in atopic dermatitis model mice, NC/Nga. Br J Dermatol 146:221

26. Jo SH, Ka EH, Lee HS, Apostolidis E, Jang HD, Kwon YI (2010) Comparison of antioxidant potential and rat intestinal a-glucosidases inhibitory activities of quercetin, rutin, and isoquercetin. Int J Appl Res Nat Prod 2:52-60
27. Vila-Real H, Alfaia AJ, Bronze MR, Calado AR, Ribeiro MH (2011) Enzymatic synthesis of the flavone glucosides, prunin and isoquercetin, and the aglycones, naringenin and quercetin, with selective $a$-L-rhamnosidase and $\beta$-D-glucosidase activities of naringinase. Enzyme Res 2011:11

28. Ramya S, Neethirajan K, Jayakumararaj R (2012) Profile of bioactive compounds in Syzygium cumini: a review. J Pharm Res 5:4548-4553

\section{Submit your manuscript to a SpringerOpen ${ }^{\circ}$ journal and benefit from:}

- Convenient online submission

- Rigorous peer review

- Open access: articles freely available online

- High visibility within the field

- Retaining the copyright to your article

Submit your next manuscript at springeropen.com 